\title{
SEQUENCE STRATIGRAPHY, QUATERNARY BASIN ANALYSES IN THE ADRIATIC FOREDEEP
}

\author{
S. GURI ${ }^{1}$, L. GJANI ${ }^{2}$, S. RANXHA ${ }^{1}$, M. GURI ${ }^{3}$, A. XHAXHIU ${ }^{3}$
}

\begin{abstract}
This paper intends to give the characterization of Quaternary loose deposits, near and along the sea coast zone, by evaluating lithological-geologic parameters, depositional environments and the tectonic subsidence. The main objectives are:

- The lithologic-facial zone by mapping of lithologic composition and facies distribution.

- The Quaternary basin analyses by interpreting depositional sequences of third order, where system tracts (lowstand, shelf wedge, transgressive and highstand) are individualized.

- The present fluvial processes and delta configuration (Shkumbin, Seman).
\end{abstract}

\section{INTRODUCTION}

The paper treats the sedimentology of Quaternary deposits in the Durres-Fier littoral zone, their relation to fluvial processes and coastline shifting.(Fig. 1)

In this context, the Quaternary basin is analyzed by interpreting the sea level changes and subsurface lithology, in the benefit of water resource exploration and discoveries.

This paper emphasizes eustasy as an important factor in recognizing the changing sea levels during the Pleistocene.

Each cycle consists of a couplet representing a lowstand and highstand of sea level. The couplets are seemingly related to the climatic changes, such as those that occur between glacial and interglacial periods.

The sedimentary response to the rising and lowering of sea level is recognized on seismic sections by onlapping or downlapping cycle termination and amplitude contrast.

These cycles are identified by multiple criteria including paleontologic, sedimentologic and seismic evidence.

Seismic-sequence interpretation is based on identification of discrete stratigraphic units within relatively conformable intervals of strata, by using reflection patterns.

KEY WORDS: Eustasy,Sequence,Sedimentology, Sandstone, Water Resource, Quaternary, Loose deposits, Subsidence.

\section{GEOLOGIC FRAME WORK}

Two main formational types represent the study area:

- Bedrock Formation (Messinian and Pliocene)

- Covering formation (Quaternary loose deposits)

\section{I-1. LITHOLOGY AND FACIES DISTRIBUTION}

\section{I.1.A - BED ROCKS}

The Messinian rocks are appeared in Currila sector and around the "rock of Kavaja". It's represented by massive clay stones intercalated with sandstones, which predominate upward. The clays are blue colored, compact and with few silty

From mineralogical point of view, based on diffractometry, the clays constitutes of montmorillonit (45$60 \%$ ), ilit (15-20\%) caolinit (10-15\%) and other minerals (up to 5-7\%). (Mahmutaj. L, 1989).

1. Oil \& Gas Institute, Department of Geology, Fier-Albania

2. Faculty Of Geology \& Mining, Tirana - Albania

3. Geological Survey, Tirana - Albania 


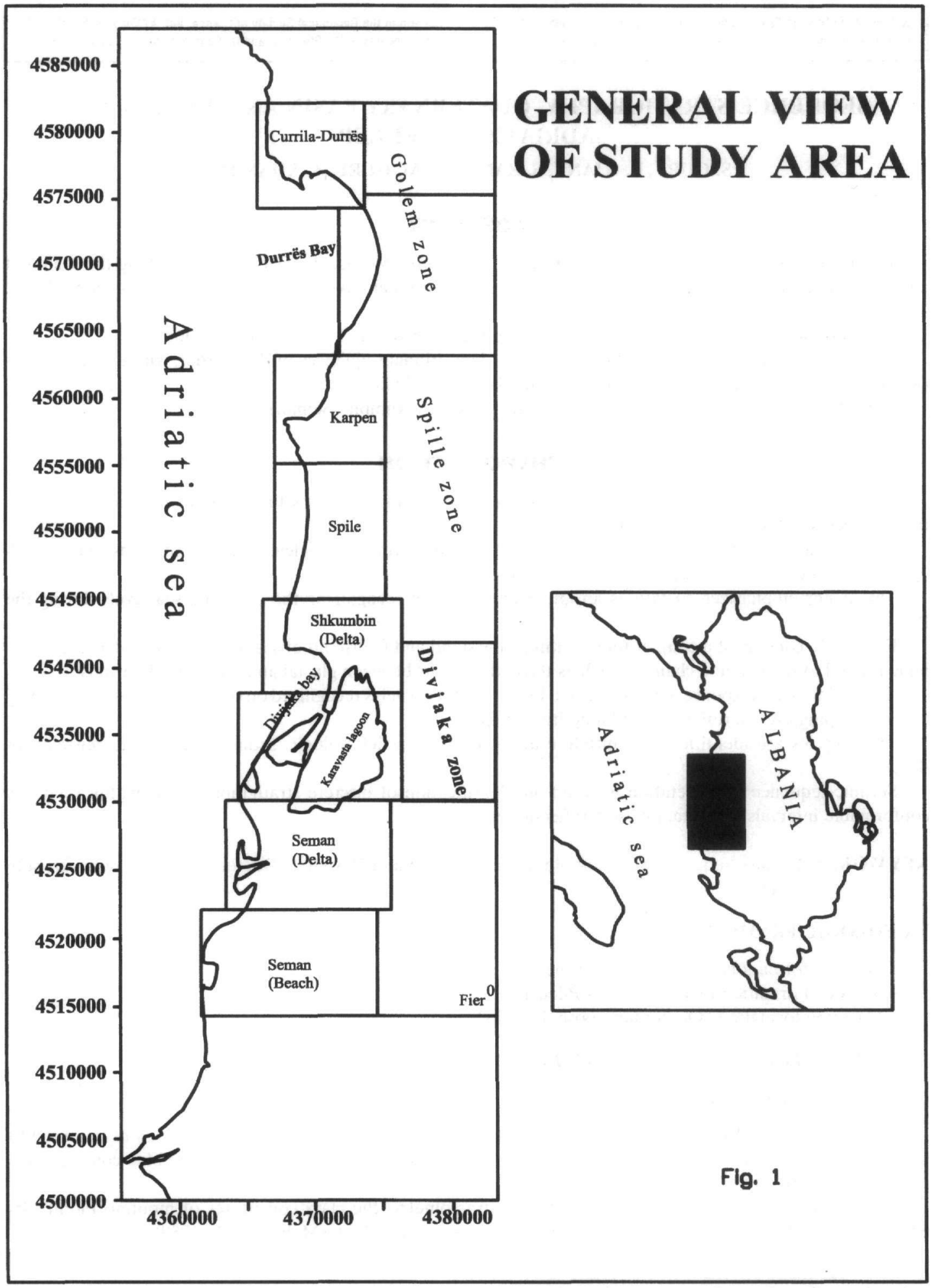


The cement is of a mixture contact, and it's mainly represented by the spatic carbonate.

Pliocene rocks take place along the eastern part of the study area, beginning from the "rock of Kavaja" down to the city of Fieri.

Two known formations take part in its constitution:

- Helmesi suite

- Rrogozhina suite

The deposits of Helmasi suit begin with basal sandstones and conglomerates, interbedded with clays that predominate upwards. Both sandstones and claystones have the same mineralogical constituents as in the Messinian.

\section{I.1.B. COVERING FORMATION}

Based on surface geology and on numerous drillings wells, the Quaternary loose deposits are considered to be composed of deluvial, alluvial, lagoon-marshes and coastal-deltas deposits.

Deluvial deposits outcrops near the foothills of bedrocks with a thickness of $4-5 \mathrm{~m}$., which is being reduced westward, going laterally and facially in alluvial ones. It's difficult to be identified in the subsurface sections, because of its similarity with alluvial ones.(fig. 2)

Alluvial deposits seize the major part of the study area, presented as a vegetal land. These are mainly represented by plastic to little compact subclays.

Near the water stream (rivers, drainages), it is represented by light subsands up to half of this century, as that of Semani, or not to have the optimal constructive rhythms as Vjosa, Shkumbini river.(SkramiJ., Guri S., 1994)

Another reason of delta destruction is the completion of the constructive cycle's period of agradational and progradational parasequence set. They prolong not more than 40-50 years. The evaluation of the above-mentioned parameters allows to forecast a definite geomorphology on the benefit and / or on the serve of water source exploration.

Medium grain size gravels saturated with waters represent them. It's also evident in the subsurface section during the highstand system tract, especially in the last one.

Lagoon and marshes deposits emerge as a strip, accompanying the beach zone. They are represented by wet up to flowing clays, with brown to dark color and with abundant quantity of organic matter, as plant remnants, cool matter, lignite and mud.

On surface, it's presented as a hypersaline land, with no vegetation.

In subsurface (well sections), it is distinguished by individualizing the coal markers or clay thickness with abundant organic matters.

The lagoon and marshes environments migrate westward to younger stratigraphic levels.(Fig. 3)

Coastal deposits consist of beach and front delta sediments. Small and medium grain size sands, gray to beige color, semicompact and with some light subclay laminations represent them.

Along the seacoast, these deposits have a thickness of $17-20 \mathrm{~m}$. On the subsurface, they took place during the respective highstand of each depositional sequence and they are preserved in the last one.

This environment also migrates westward to younger stratigraphic levels.

\section{THE QUATERNARY BASIN ANALYSES}

\section{II.1. INTERPRETATION OF DEPOSITIONAL (SEISMIC) SEQUENCE}

In correspondence with sequential analyses of world basin (Possamentier, et al 1988), in the Quaternary thickness, three depositional sequences of third order have been recognized. It's noticed that the Quaternary initiated its "life" since 1.6 million years in more restricted space than the former (Pliocene) with a depocenter more westward.

It is surrounded by an intensive orogen, in both sides (Appenines and Albanides), with a strong relief.

\section{The sequence - $A$}

This sequence took place soon after the sea level fall at the latest Pliocene, in accordance with the global sea level changes Chart, too.

In our basin, it is confirmed by evidencing a sequence boundary of $\mathrm{Sb}_{1}$ type, in Apsi-Pisha zone, near Karavasta lagoon, where this boundary surface is onlapped and toplapped by seismic reflection groups.(Fig.- 4)

This boundary belongs to a new sequence (Guri S., Xhango V., 1986). The Quaternary base is correlated 
FIG.2. SCHEME OF HOLOCENE DEPOSITIONAL ENVIRONMENTS SHKUMBIN-SEMAN AREA 2001

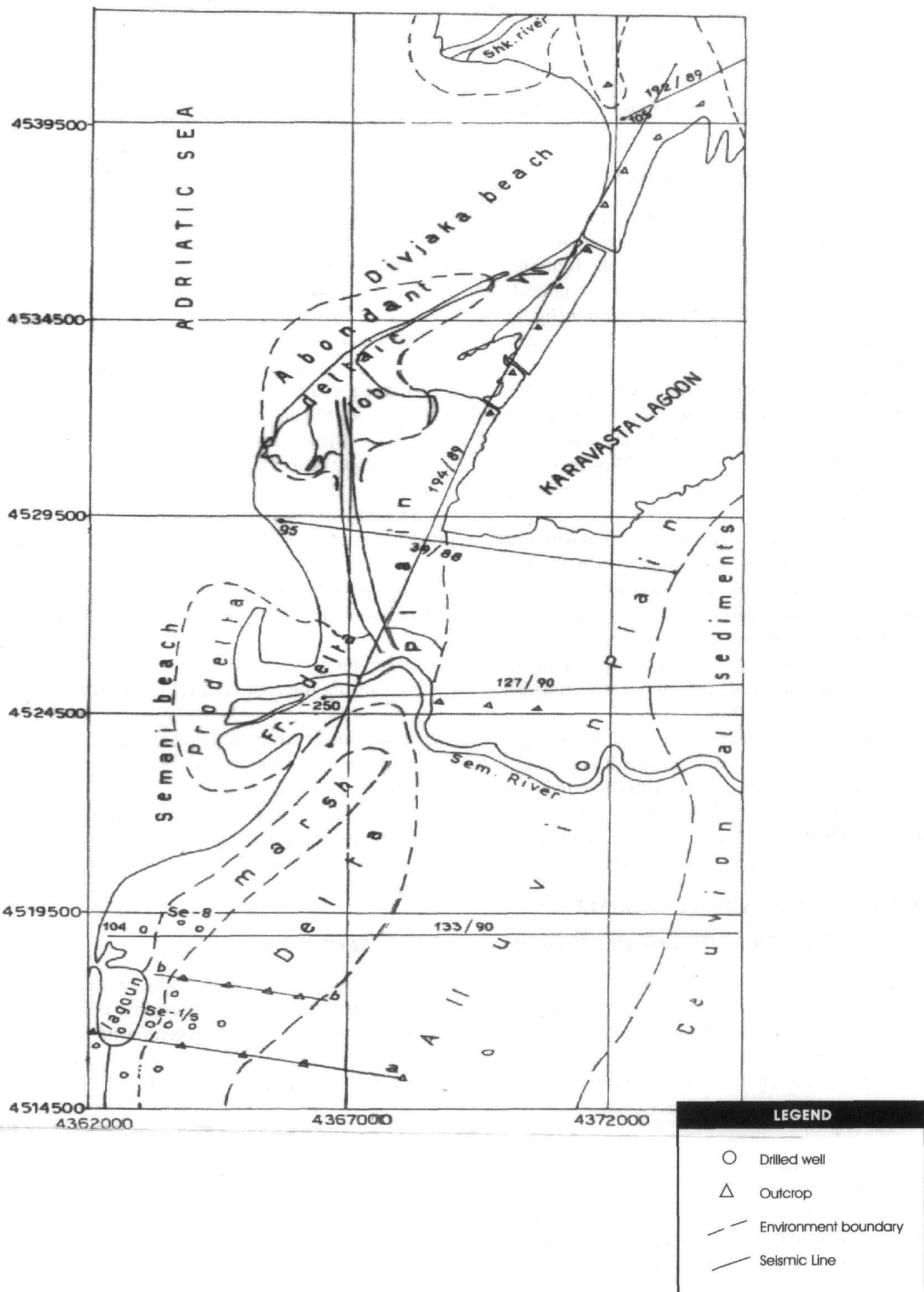


through regional seismic lines of Albanian offshore (Guri S., Mehillka Ll. 1995), with the real Quaternary base of Italian offshore.

A progradational facies (oblique and sigmoid one) is encountered in the middle of Adriatic Sea. Together with some other data, it indicates that the first Quaternary sedimentation belongs to lowstand system tracts.

Then, we come across in the Albanian onshore (seismic line 192/89, Karavasta) the transgressive and highstand system tracts "expressed" by a distinctive unconformity near the sea coast (in the western side of the neogen anticlined structures).

An aggradational facie accompanied by strong and continuous seismic reflections rather indicate shelf condition sedimentation of highstand system tracts.

The thickness of this depositional sequence attains $800-1200 \mathrm{~m}$ offshore, and 200-300m in Albanian onshore.

\section{The sequence $-B$}

The second depositional sequence took place 800 thousand years ago. Its boundary surface is encountered in both sides of Quaternary basin (offshore seismic lines), where onlapped reflection termination is observed. (seismic line 39/88, Divjake).

The nature of reflections and their geometry indicate an inner shelf sedimentation of (Albania onshore) and an outer shelf to basin (Albania-Italian offshore).

Parts of transgressive and highstand system tracts, with prodominant fluvial processes, are interpreted in the study area. The sedimentary environments (alluvial plain, deltaic plain, lagoon, marshes, delta fronts) migrate westward to younger stratigraphic levels.

\section{The sequence - $C$}

The third sequence belongs to Holocene and has just taken place with its sediments not farther than 0.05 million years ago. There is no noticed the lowstand system tract away in offshore, but we can deal with that of highstand in our study area., The presence of fluvial processes is typical and better preserved than in the older sequences.

\section{II.2. BRIEFLY ON AREA GEODYNAMIC}

The thickness of Quaternary deposits cover several neogen structures as:

- Povelçe - Seman

- Divjake - Ballaj - Kryevidh

- Golem - Kavaj - Shkoze

which are related to the orogenic tectonic. As a consequence, overthrusted and backthrusted faults accompany them, where the key role generally belongs to the overthrusted one. (Scientific Report, Appenines Helenides Geodynamic)

Occassionaly, where neogen structures are nearby the competent masses (carbonate structures), triangular zones are formed, and the key role of faults is exchanged passing to the backthrusted one, such as in Durres, Preze, Ardenice.

A feature of tectonic faults is the diminution of their range toward the surface that does not often appear on the ground. The Plio-Quaternary deposits are not often affected, neither by overthrusted or backthrusted faults.

But, their evidences toward the surface take importance for the fact

that, these faults play a key role in fluvial processes, coastline shifting, in the distribution of water reservoirs and in seismicity of the zone.

Another feature of tectonic active faults is the diminution of their range northwards, as well. So, the faults of Zvernec-Poro-Povelne-Seman and that of Kraps-Ardenice-Divake-Kryevidh do not respectively continue or lose the orogenic role seawards.

The structural plane continues to preserve the same values originated since Tortonian, where a subsidence of above-mentioned structures is evidenced. Besides the overthrusted faults that accompany the neogen structures, we come across transcurrent system faults, just where the key role of the overthrusted fault is passing to the backthrusted one (Ardenice-Divjake, Kryevidh-Durres)

This fault type directly influences in the formation of subsidence zones. They also effect in the destruction of deltas (Seman), especially during the ingression of the sea.

As above, we can draw the conclusion that the tectonic and neotectonic take directly part in the eustatic sea level processes by creating a relative sea level change, in the overthrusting and / or subsidence zones. 


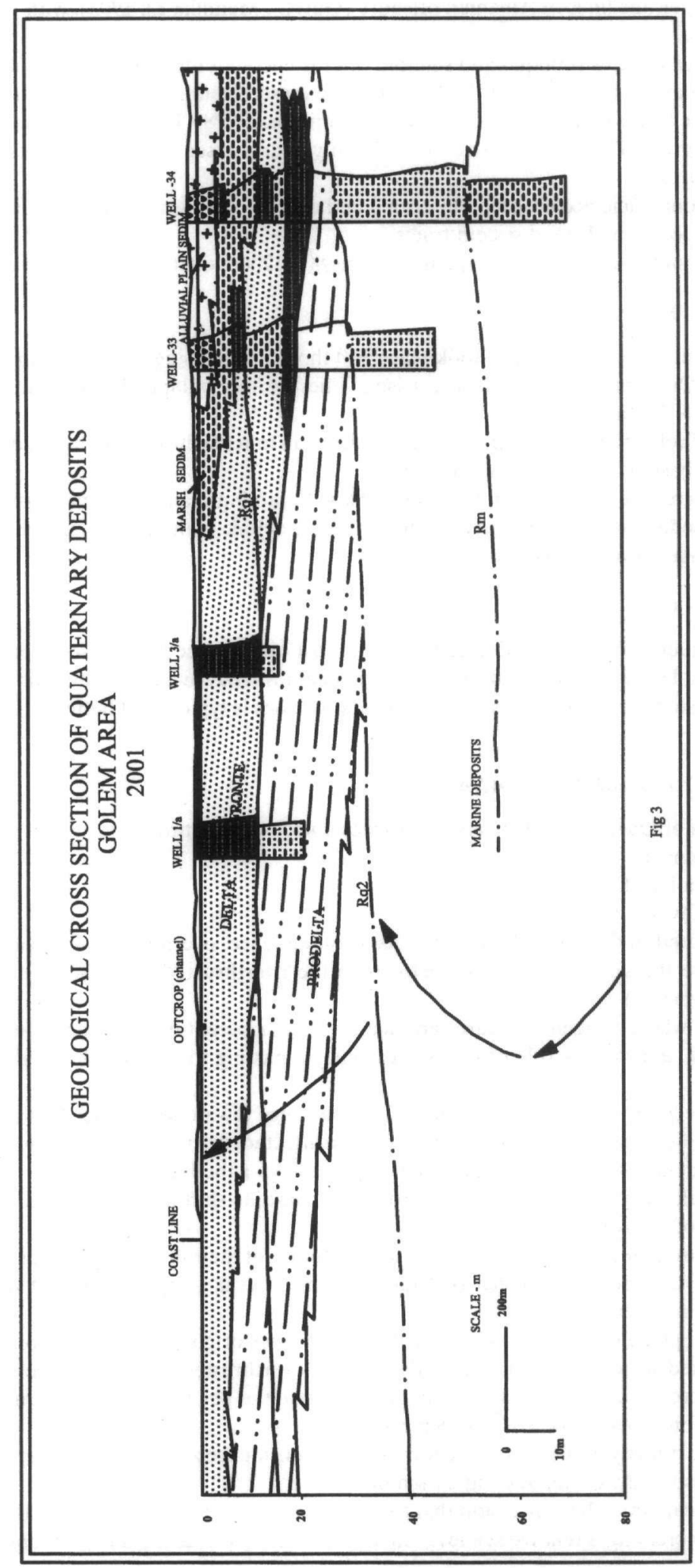




\section{II.3. ACTUAL SEDIMENTOLOGY}

Eustasy, tectonics, climate are three of factors controlling the coastal line shift in each position of globe.

During last century, it seems that a postglacial period has been established. The glaciers melting caused an increasing of eustatic sea level change, but combining with a determined tectonic factor, it brings out the falling or rising of this level.

Practically, the zone of Seman-Spile and the Karpen-Golem one present features of subsidence zones because of structural plane character, which always dips from south (Zvernec, Kraps) to the Quaternary basin depocenter.

During this century, the tectonic processes and the eustatic sea level changes have created in these zone conditions for a shift of coastal line toward orogen. Being that these deposits coincide with late highstand, where the fluvial processes dominate or determine control the sedimentation. Large delta plains are formed accompanied with respective delta fronts as those of Seman, Shkumbin rivers and generally occurs an aggradation of river side or a displace of shoreline seaward and / or formations of landtracts.

The humid climate and the vicinity of source rocks contributes to large sedimentary loads, which limit the aggressivity of the sea, but not stopping it into interdeltaic zones. Basing on these data, we can understand the presence of the interdeltaic zone between Vjosa and Semani delta, or Semani and Shkumbini one, etc.

During the last years, the human interference in natural processes has caused the diminution of sedimentary loads. The combination of this factor with those mentioned above (tectonic, eustasy) have made possible to be destroyed the geomorphologic equilibrium, on the detriment of the formation of new land such as delta front, beaches, delta plain, marshes lagoons etc., creating in this way new delta fronts, delta plain, beaches, marsh etc.

On the other part, this have caused the demolition of old deltas formed in the first sequences.

\section{CONCLUSIONS}

1.- Two main formational types represent the study area:

- Bedrock's formation (Messinian and Pliocene)

- Covering formation (Quaternary loose deposits)

The first is represented by massive claystones intercalated with sandstones, which predominate upward.

Two known formation take part in the Pliocene rocks constitution:

- Helmesi suite

- Rrogozhina suite

The deposits of Helmasi suite begin with basal sandstones and conglomerates.

2.- The Quaternary is composed of deluvial, alluvial, lagoon-marshes and coastal-deltas deposits.

3.- Three depositional sequences of third order have been recognized.

These sequences took place soon after the sea level fall at the end of upper Pliocene, where the boundary surface is onlapped and toplapped by seismic reflection groups.

The second depositional sequence occurred 800 thousand years ago. Its boundary surface is encountered in both sides of Quaternary basin. The nature of reflections and their geometry indicate an inner shelf sedimentation of (Albania onshore) and on outer shelf to basin one (Albania-Italian offshore).

The third sequence belongs to Holocene and has just taken place with its sediments not farther than 0.05 million years ago. There is no noticed the lowstand system tract

4.- The Quaternary deposits cover several neogenic structures, which are related to the orogenic tectonic.

The tectonic and neotectonic take directly part in the eustatic sea level processes by creating the relative sea level change, in the overthrusting and / or the subsidence zones.

The tectonic processes and the eustatic sea level changes have created in these zones conditions for a shift of coastal line towards orogen.

5.- The human interference in natural processes has caused the diminution of sedimentary loads.

The combination of this factor with those mentioned above (tectonic, eustasy) led to the destruction of the geomorphologic equilibrium, in this area. 


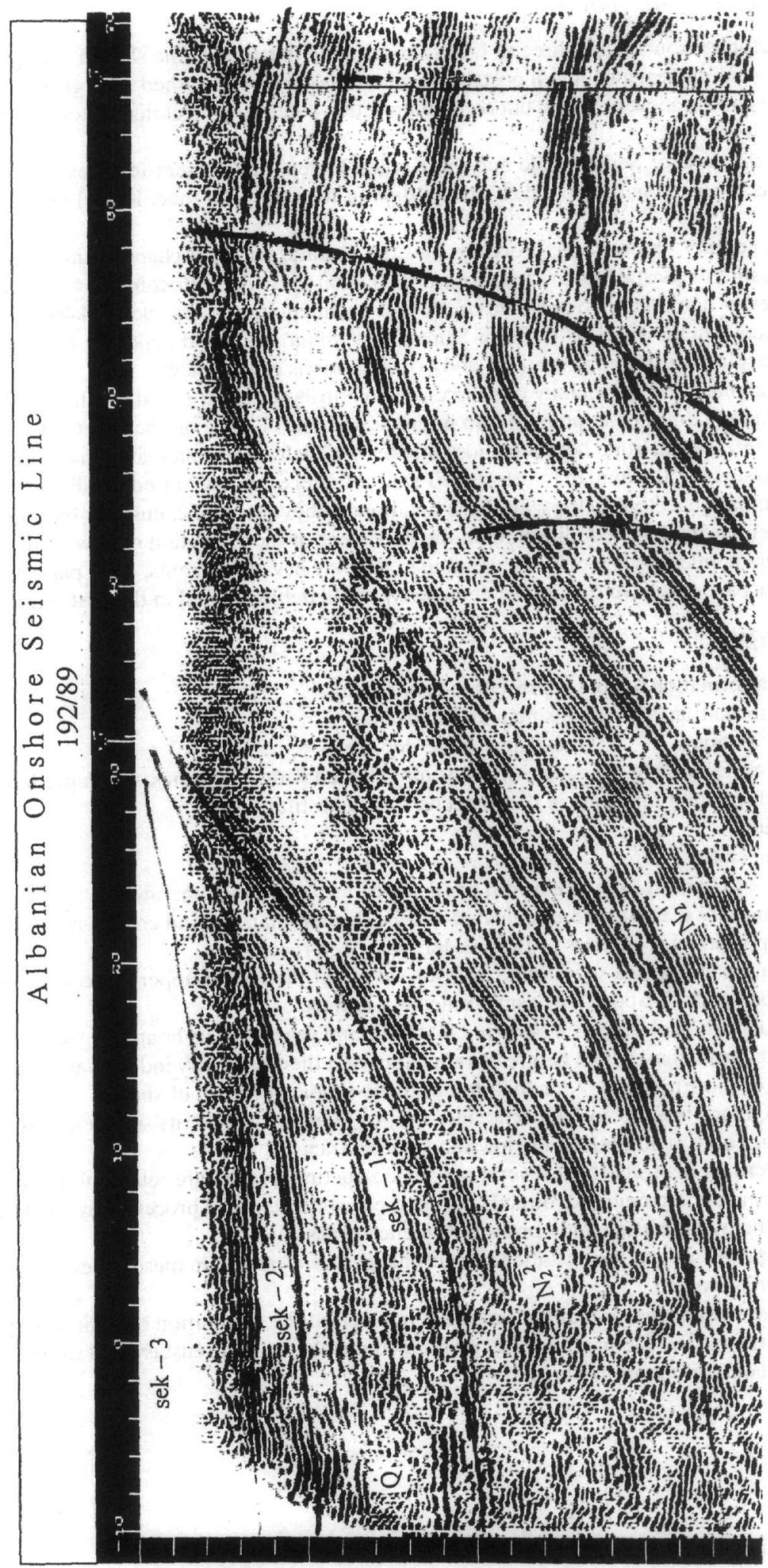




\section{REFERENCES}

GURI S, ISMAILI J. - 1993 -The basin study of the Preadriatic Depression (Albania). Archive of Oil and Gas Institute, Fier

GURI S.,XHANGO V. - 1986 -The geologic - geophysical study in the Divjaka gasfield region. Archive of Oil and Gas Institute, Fier

GURI S., MEHILLKA LL. - 1995 -The structural model of external Albanides and hydrocarbon prospects Archive of Oil and Gas Institute, Fier

MAHMUTAJ L. - 1989 -The mineralogic - petrographic study of clayrocks in pre Adriatic depression. Archive of Oil and Gas Institute, Fier

POSSAMENTIER, H.V. et al - 1988 - Eustatic controls on clastic deposition SEPM Special Publication, 42 p. 109 $-154$

Scientific Report, Appenines - Helenides Geodynamic

SKRAMI J., GURI S. - Some trends of the study of Quaternary loose deposits on the Durres-Vlora coastal zone. Publicize of "Universita degli Studi di Bari” (Italy),p. 185-187 Gennaio, 1999 Scientific Library of Oil \& Gas Institute, Fier - Albania

ZEQO B. - 1989 -The geologic field survey of Durres - Kavaje area in scale 1: 25000 Archive of Oil and Gas Institute, Fier 